\title{
Digital technologies in the development of visual languages: reflections on experiences of image creation from case studies
}

New techniques and possibilities of image reproduction are now multiplying and getting diversified. This technological plurality has influenced the way of making and thinking the visual arts, particularly after the 1950's. Technological artists are more focused on the processes of artistic creation and esthetical exploration than on the production of finished works. Within this context, this article discusses the use of digital technologies in the creation of images from an educational experience in an undergraduate course in Design. After a bibliographic survey, we have analyzed three works developed from the same proposal, which was executed by using digital technologies. The proposal consisted of reading a tale by Ítalo Calvino and its further transposition into the visual language. The purpose was to stimulate imagination and creative gesture by looking for an original sight, even if obtained by means of technological resources, which are generally meant for the reproduction of images. By looking at the results reached by students, we observed that the portrayal of everyday landscapes and objects showed to be an efficient pedagogical strategy in that, without dispensing the poetical and original sight, it was converted into a possibility of connection with the tangible world, in a counterpoint to the growing predominance of the virtual space.

keywords visual design, technology, education, creative processes

\section{Introduction}

Printed reproduction techniques come from ancient times. In the Eastern world, we have woodcut and serigraphy; in the Western world, the reproduction from relief and casting, typecasting, metal engraving and etching, and in the 19th century, lithography and a photography. This multiplicity of technologies influenced the form of doing and thinking the visual arts in different historic and cultural moments (Benjamin 2012).

Technical changes have implications to thought and visuality, and impact teaching strategies. These changes imply in new practical, social and cognitive analogies and classifications (Lévy 1993).

Teaching the creation of images in the contemporary world involves the use of technologies: digital cameras, scanners, softwares. In what measure these technical resources favor the construction of visuality and how they interfere in the creative process.

The purpose of this work is to make this discussion by using a bibliographic survey and teaching experience in an undergraduate course in design, aiming to contribute to a reflection on the education-learning process. 


\section{Bibliographic survey}

Walter Benjamin discussed the esthetic modifications in art from the advent of technical reproductibility, according to three concepts: originality, authenticity and unity. The firstone is based on the here-now principle; authenticity makes a dialogue with the originality of the work, and unity would be related to its insertion in tradition. This author also discussed the fact that human perception is not only defined through its physiological principles, but is also historically and socially conditioned.

Under the technological point of view, we can think of the production of art along time according to three moments: artisanal, industrial and electrical-electronic (Plaza 2003a). The introduction of new technologies in art was intensified from the 1950's. Max Bense started the so called "Generative Aesthetics" by proposing random processes generating computerized images (Plaza 2003a).

Max Bense and Jasia Reichardt headed the exhibition "Cybernetic Serendipity" (London, 1968), which exhibited in first hand works created with the computer and created a controversy about the artistic value of images obtained through technological processes, which favor the production of "open", collaborative, multi-sensorial, interactive and innovating works.

From 1980's, many theoreticians began to think of the specificities of digital culture. Ascott (2003) introduced the concept of "technoethics", which would be "the fusion between what we know and what we still can discover about consciousness (noetics)". Quéau (1985) established connections between digital media art and living nature processes.

Manovich (2001) affirmed that interface is one of the primordial elements of the computer society, allowing a rupture with the old dichotomy between form and content, as "content and interface merge in such a way, that they cannot be thought of as separated entities anymore."

Dorfles (1995), however, alerted us of the dangers of an uncritical meeting of culture and technology. We can be easily fascinated with the infinity of possibilities and dimensional freedom, which would disfavor an authentic artistic experience, as they don't lead to esthetic enjoyment or artistic appreciation.

Rénaud (1989) points out to the risks we undergo with the free use of new technologies, but considers that, if well used, they can be "experimental laboratories" of visual sensitivity.

It seems unquestionable that the level of knowledge and technique of designers impacts the quality of products developed by them. However, innovation appears when the individual is not completely constrained to reality, logics and technique (Pombo and Tschmmel, 2005).

Perception is a dynamic, selective and creative process that includes previous experiences, emotions and expectances (Roth, 2000). However, it is necessary to consider that the expression of this perception by means of the visual language also takes into account the mastering of technique, and that the multi-sensorial environment in which we live also influences this perception. 
Technical changes have implications in thought and visuality, and impact teaching strategies: "If, as affirmed Lévi-Strauss, techniques are a part, product and condition of culture, it is not possible to think of art teaching in a way dissociated from its material conditions of production and circulation, because that would imply in transforming a given system into an absolute one." (Fabris 2005)

\section{Method \\ Didactic proposal: from verbal to visual}

The experience here presented was accomplished during the undergraduate degree in Design', in the course on Visual Languages, which objective is to exercise perception, the elaboration and representation of images, by exploring the transposition of languages (literature and design). Classes were based on the development of practical works with varied techniques, by aiming to explore experimental creative processes in visual design. The proposal consisted in reading and interpreting the tale "Um sinal no espaço (A sign in space)" from the book As cosmicômicas by Ítalo Calvino. Calvino finds stimuli in science to make literature: each tale begins with a scientific enunciation regarding the formation of the cosmos, and develops fantastic narratives focused on human relations. Calvino reminds us that imaginative capacity is required for giving visibility both to science and to literature.

The reading of this tale worked as a literary stimulus for the visual creation. Students were encouraged to be open to the most varied interpretations. They presented their recordings of imagined or visited signs and spaces - trees in a park, reflections of light, shadows on a crumpled paper, a window open to the sky, the space of the body, etc. Students freely chose procedures, materials and techniques. Several opted for photography, probably because of easiness and familiarity with this medium. Photographs produced by them were then edited in small image books, like the examples below.

\section{Results: signs and spaces}

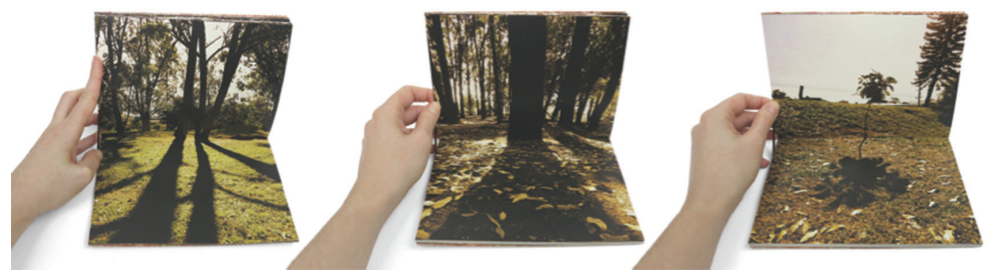

Figure 1.

Student: Sabrina

Duarte (2013)

Photography.

In this proposal (Fig. 1), the student chose to record the form of trees and their shadows as signs, and the nature as space. She photographed various trunks, treetops, and their respective shadows in the soil. The visual message she expresses based on what she has seen in the environment and along her experience acts at a representational level. In the image, one perceives a depth of field that evidences the point of view of the static observer, typical of the classical perspective.

Photography is a certification of presence; it infinitely reproduces what occurred just 
theme 4

technology

Figure 2.

Students: Fernanda Tottero and Felipe Cavalheiro (2013). Photography. strand 2

materials, techniques and processes

once (Barthes 1984). The photographic device captures the trace of light. However, more than a mechanical recording, the photographic image embodies the way of seeing of the photographer, a specific scene among other infinite possibilities (Berger 1974).

When planning her image book, the student positioned the line of the photographed horizon precisely over the spine of the book, with the horizontal and vertical plans - ground and air - divided into the opposite pages, forming a $90^{\circ}$ angle in the book. Therefore, she reaches a sophisticated fusion between the object (book) and the syntax In this proposal (Fig. 2), the students performed different experiments with the surface of paper (punctures with needles, kneading and stretching, humidifying, etc).Next, they
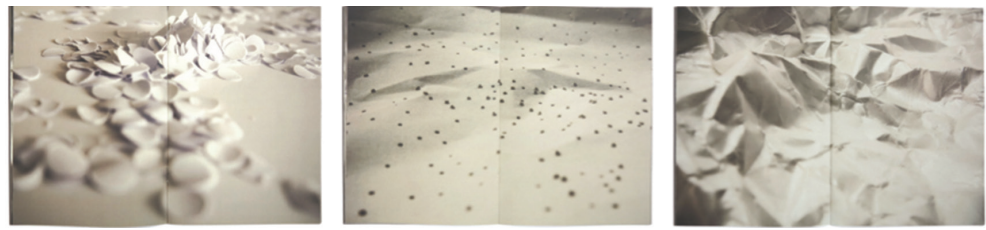

studied possibilities of modulating light over the spatial surface and documented it under different angles. Resulting images communicate the "visual tact" (Aumont 2012: 146) metaphor through an emphasis to image surface and volume of the represented object. Scenes photographed by them were previously planned and assembled. The intention precedes the photographic gesture: "the manipulation of the device is a technical gesture, i.e., a gesture that articulates concepts. The device obliges the photographer to transcode his/her intention into concepts before being able to transcode it into images." (Flusser 2011: 52-53). In other words: the photography required the awareness of his/her intentions, followed by an elaboration of ideas and concepts.

At each step of this experience, made through the combination of material supports and digital photography, empirical discoveries indicated the paths to be taken. Digital photography enables a verification of resulting images at each click, what contributes and accelerates the awareness of the creative process, a knowledge that leads to new actions. This thought that arises from doing something is called reflection-in-action by Schön (1983) and Dorst (1997), having the latter, together with Cross, extended this concept into "Co-evolution of Problem-Solution" (2001).

While with the language of drawing mimesis and imitation of real life were many times forcedly sought, paradoxally the use of photography liberates students to create, not only to simply capture the visible world. Photography can be more than a snip of real life when it articulates concepts and transcends the documental value. The device controls the meeting between spectators and image (Aumont 2012), and can stimulate and amplify the perception (Lévy 1996) 

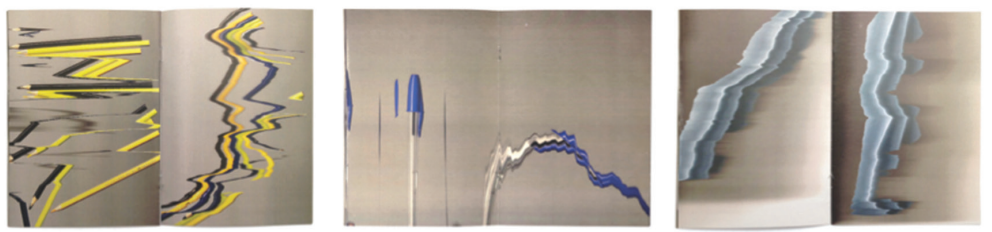

Figure 3 .

Student: João

Schmitt (2013)

Scan.. Photography.

In this case (Fig. 3), the student positioned objects on the scanner and opened its cover during the scanning process. This gesture plays with the device in an unexpected way.

"The device becomes a toy, not an instrument in the traditional sense, and the man who manipulates it is not a worker, but a player: no more a homo faber, but a homo ludens, and such man doesn't play with his toy, but against it. He tries to exhaust its program." (Flusser 2011: 43)

The scanner is a device dedicated to digitalize documents, normally not employed to create images. In an intelligent and sensible way, the student breaks with its reproductive function, and invents a new creation medium which didn't exist before. By emphasizing the characteristics of the medium he uses, he renders it self-referential, i.e., he employs its very materiality as a sense triggering element (Plaza 2003b).

What could be considered as an error is converted into semantic innovation. The unpredictable resulting image is a diagram of this action. The relationship between chance and intention reveals the dialectics of the creative movement (Salles 2004).

It is possible to observe that designers frequently change objects and project characteristics during the creative process, be it as a result of difficulties or insights. According to Gestalt's theory, an insight is the result of a reorganization of a perceptual field (Puente Ferreras, 1999, p. 227).

The unconscious has its own language, and can be expressed in the domains of arts and design, besides other fields requiring creative and innovating solutions. The departing point of thought is the perception, which selectivity always has an arbitrary component (Pombo and Tschmmel, 2005).

\section{Final considerations}

The observation of these creative processes shows that each designer interprets the same problem in a single and subjective way. Therefore, solutions are specific options that include aspects less tangible of creativity as well as the mastering of a technique and its representative possibilities.

Considering that perception is restricted to our personal universe and repertoire, the fact of dedicating more to contemplation to the detriment of quotidian automatic activities might positively stimulate the creative process.

In this sense, the role of design education would lead to the exercise of a "free" and "creative" perception, diluting stereotyped habits of perception and thought through the accomplishment of practical exercises from conceptual projects and approaches. As technical resources interfere with the construction of visuality as much as sensible 
perception, they should also be mastered by the artist/designer, even if applied within the scope of experimentation.

Before the results reached by students, we verified that the recording of quotidian landscapes and objects was converted into an efficient pedagogical strategy, in that it evoked the poetic sight swiftly registered through photography or scanning.

\section{References}

Arantes, P. (2005) Arte e mídia no Brasil: perspectivas da estética digital. ARS, vol. 3, no. 6, pp. $52-65$

Ascott, R. (2003) Quando a onça se deita com a ovelha: a arte com mídias úmidas e a cultura pósbiológica. In Domingues, Diana (org.). Arte e vida no século XXI: tecnologia, ciência e criatividade. São Paulo: Editora da Unesp, p. 274.

Aumont, J. (2011) A imagem, Campinas: Papirus.

Barthes, R. (1984) A câmera clara: notas sobre a fotografia. Rio de Janeiro: Nova Fronteira.

Benjamin, W. (2012) A obra de arte na época de sua reprodutibilidade técnica. Porto Alegre: Editora Zouk.

Berger, J. (1974) Modos de ver. São Paulo: Martins Fontes.

Dorfles, G. (1995) Interferenze tra Arte e Tecnica in Rapporto ai Nuovi Media. In Epipháneia, Napoli, May, pp. 32-33.

Dorst, K. (1997) Describing design: a comparison of paradigms. Delft: Delft University Press. Dorst, K; Cross, Nigel. (2001) Creativity in the design process: coevolution of problemsolution. In Design Studies, vol. 22, no 5, Setembro, Elsevier Science Ltd., pp. 425 - 437. Fabris, A. (1998) Redefinindo o conceito de Imagem. Revista Brasileira de História, vol. 18, no. 35.

Flusser, V. (2011) Filosofia da caixa preta, São Paulo: Annablume.

Lévy, P. (1993) Les Téchnologies de l'Intelligence. Paris: Seuil.

Lévy, P. (1996) O que é o virtual? São Paulo: Ed. 34.

Manovich, L. (2001) The language of new media. Cambridge: MIT Press, p. 67.

Plaza, J. (2003a) Arte e Interatividade: autor - obra - recepção. ARS, vol 1, no. 2,

December, pp. 9-29

Plaza, J. (2003b) Tradução intersemiótica. São Paulo: Perspectiva.

Pombo, F; Tschimmel, K. (2005) O Sapiens e o Demens no pensamento do design: a percepção como centro. Revista design em face, v 2, no 2, pp 63-76.

Puente Ferreras, A. (1999) El cerebro creador: psicologia. Madrid: Alianza Editorial. Quéau, P. (1985) Metaxu: théorie de l'art intermediaire. Paris: Champ Vallon.

Rénaud, A. (1989) "Pensare l'Immagine Oggi. Nuove Immagini, Nuovo Regime del Visibile, Nuovo Immaginario". In V.A., Videoculture di Fine Secolo. Napoli, Liguori, pp. 11-27.

Roth, G. (2000) Erkenntnis und Realität: das reale Gehirn und seine Wirklichkeit. In Schmidt, Siegfried J. (Ed.). Der Diskurs des Radikalen Konstruktivismus. 8. Ed. Frankfurt am Main: Suhrkamp Taschenbuch Verlag, pp 229 - 255.

Salles, C. (2004) Gesto inacabado: processo de criação artística. São Paulo, Annablume. Schön, D. (1983)The reflective practitioner: how professionals think in action. New York: Basic Books. 